\section{Perception on bioethics and animal welfare by veterinarians}

\author{
Percepção sobre bioética e bem-estar animal por \\ médicos veterinários
}

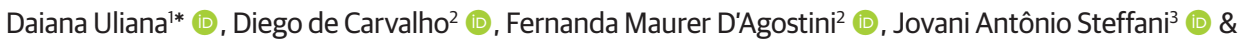 \\ Elcio Luiz Bonamigo 4 (D) \\ 'Veterinarian, MSc. Graduate Program in Biosciences and Health, Universidade do Oeste de Santa Catarina - UNOESC, Joaçaba, \\ SC, Brasil \\ 2Biologist, PhD. Graduate Program in Biosciences and Health, Universidade do Oeste de Santa Catarina - UNOESC, Joaçaba, \\ SC, Brasil \\ ${ }^{3}$ Audiologist, PhD. Graduate Program in Biosciences and Health, Universidade do Oeste de Santa Catarina - UNOESC, Joaçaba, \\ SC, Brasil \\ ${ }^{4}$ Physician, PhD. Graduate Program in Biosciences and Health, Universidade do Oeste de Santa Catarina - UNOESC, Joaçaba, \\ SC, Brasil
}

\begin{abstract}
The present study investigated veterinarians' perceptions of bioethics and animal welfare training. Participants were divided in two groups: Group 1 graduated in or before 2003, and Group 2 graduated after 2003. One hundred forty participants completed the questionnaire: 62 (44.3\%) from Group 1 and 78 (55.7\%) from Group 2. One participant (1.6\%) in Group 1 and 8 participants (10.2\%) in Group 2 were taught bioethics as an elective or required course before graduating ( $\mathrm{p}=0.003)$. Fifty-nine participants (95.2\%) from Group 1 and 75 (96.2\%) from Group 2 believed that a bioethics course should be required to graduate ( $\mathrm{p}=0.959)$. Four participants (6.4\%) from Group 1 and 24 (30.8\%) from Group 2 were taught animal welfare as an elective or required course before graduating ( $p=0.003$ ). Fifty-seven participants (91.9\%) from Group 1 and 77 (98.7\%) from Group 2 believed that animal welfare should be required to graduate $(\mathrm{p}=0.959)$. All participants considered both subjects highly relevant to the profession. Most participants were not taught bioethics or animal welfare courses before graduating; however, the availability of these courses increased after 2003. It was concluded that more emphasis should be given to teaching bioethics and animal welfare in veterinary undergraduate training.
\end{abstract}

Keywords: bioethics, animal welfare, veterinary medicine, teaching, higher education.

\section{Resumo}

O objetivo deste estudo foi conhecer a percepção de médicos veterinários sobre formação em Bioética e Bem-Estar Animal. Os participantes foram divididos em dois grupos: Grupo 1 composto por profissionais formados até 2003 e Grupo 2, depois de 2003. Responderam ao questionário 140 participantes, sendo 62 (44,3\%) do Grupo 1 e 78 (55,7\%) do Grupo 2. Houve1(1,6\%) participante do grupo 1e 8 (10,2\%) participantes do Grupo 2 que tiveram a disciplina Bioética durante a graduação na forma optativa ou obrigatória ( $p=0,003)$. Consideraram a disciplina Bioética necessária para a formação, 59 (95,2\%) participantes do Grupo 1 e 75 (96,2\%) do grupo 2 ( $p=0,959)$. Tiveram a disciplina Bem-Estar Animal durante a graduação, na forma optativa ou obrigatória, 4 (6,4\%\%) participantes de Grupo 1 e 24 (30,8\%) do Grupo 2 (p=0,003). Consideraram a disciplina Bem-Estar Animal necessária para a formação 57 (91,9\%) participantes do Grupo 1 e 77 (98,7\%) do grupo 2 (p=0,959). Todos os participantes consideraram ambas as disciplinas muito importantes para a profissão. A maioria dos participantes não teve a disciplina de bioética durante a graduação, mas houve aumento da oferta após 2003. Concluiu-se que maior ênfase deve ser dada ao ensino da Bioética e Bem-Estar Animal durante a graduação do médico veterinário.

Palavras-chave: bioética, bem-estar animal, medicina veterinária, ensino, educação superior.

\section{Introduction}

Decisions regarding moral conflicts associated with animal healthcare present challenges inherent to veterinary practice. Among animal owners, veterinarians and patients regarding animal healthcare delivery, the bioethical principles that guide human behavior toward animal welfare are often unobserved (Carvalho et al., 2018). \section{B] M Brazilian Journal of Veterinary Medicine \\ p-ISSN 0100-2430 e-ISSN 2527-2179

How to cite: Uliana D., Carvalho D., D'Agostini F. M., Steffani J. A., \& Bonamigo E. L. Perception on bioethics and animal welfare by veterinarians. Brazilian Journal of Veterinary Medicine, 41 e101619. doi: 10.29374/2527-2179.bjvm101619

Financial support: This research was partially funded by Programa de Apoio à Divulgação do Conhecimento - Modalidade II FAPE/UNOESC.

Conflict of interests: No conflict of interests declared concerning the publication of this article.

Received: December 17, 2018

Accepted: October 13, 2019

The study was carried out at Program in Biosciences and Health, Universidade do Oeste deSanta Catarina-UNOESC, Joaçaba, SC, Brasil

\section{*Correspondence}

Daiana Uliana

Programa de Pós-graduação em Biociências e Saúde, Universidade do Oeste de Santa Catarina - UNOESC

Rua José Firmo Bernardi, 1591, Bairro Flor da Serra

CEP 89600-000 - Joaçaba (SC), Brasil

E-mail:daiuliana@gmail.com 
Moral conflicts are common from the moment veterinary students begin their training when faced with the arguments used to justify animal use in teaching when evidence suggests that alternative techniques are equally or more effective. The increased frequency of moral conflicts resulting from scientific advances requires professionals to develop critical awareness and to be able to express, when needed, conscientious objections based on scientific and ethical reflection for the sake of animal welfare (Ballesteros, 2012).

Within such context, a directive to train veterinarians based on ethical and bioethical principles was introduced at the beginning of this century with the approval of the Conselho Nacional de Educação (National Education Council)/Câmara de Educação Superior (Higher Education Council) (CNE/CES) Resolution no. 1, on February 18 ${ }^{\text {th }}, 2003$, which institutes the curriculum guidelines for veterinary medical courses and includes specific instructions for teaching ethics/bioethics (Brasil, 2003).

Similarly, Law no. 11,794/2008, known as the "Arouca Law," addresses the scientific use of animals and established creation of the Conselho Nacional de Experimentação Animal (National Council on Animal Experimentation; CONCEA) and Comissão de Ética no Uso de Animais (Animal Use Ethics Committee; CEUA). This law is regulated by Decree no. 6,899, from 15 July 2009, in which the main goal is to "enact and enforce norms for the humane use of animals for teaching and scientific research" (Brasil, 2008, 2009). This represents an advancement in the legislation, which, together with the acknowledgment of animals as sentient beings in 2012 by scientists in Cambridge, brought together arguments to guide humans to treat animals more respectfully within or outside the scientific milieu (Low, 2012).

The World Organization for Animal Health's (OIE) understanding was no different. Per the OIE, undergraduate veterinary students should acquire knowledge on animal welfare and legislation (Organización Internacional de Salud Animal, 2013). In this regard, in a document published the previous year, OIE observed that recent graduates should be able to explain the notion of animal welfare (Organización Internacional de Salud Animal, 2012).

The Conselho Federal de Medicina Veterinária (Brazilian Federal Council on Veterinary Medicine; CFMV) included animal welfare guidelines in the last edition of the Code of Professional Ethics, through CFMV Resolution no.1,138, from December 2016. These guidelines were also included in the Fundamental Principles, thus consolidating the concept of animal welfare within the scope of professional ethics and supporting its acknowledgment by veterinarians (Conselho Federal de Medicina Veterinária, 2016).

Although CNE Resolution no. 1/2003 on instructing teaching ethics/bioethics (which also implies "animal welfare") in veterinary training has been enforced for more than a decade, the level of compliance with this resolution is unknown (Brasil, 2003). Based on the legislation's context and the few publications on teaching bioethics at veterinary schools in Brazil, the present study aimed to describe the perception of two groups of veterinarians who graduated before (Group 1) and after (Group 2) CNE Resolution 1/2003 was enforced.

\section{Materials and methods}

The present observational, quantitative, descriptive, exploratory study, which included a survey, was approved by a research ethics committee, ruling no. 1,543,634. Participants were veterinarians allocated in two groups: Group 1 graduated in or before 2003, and Group 2 graduated after 2003. The rationale for this grouping was the 2003 publication of CNE/CES Resolution no.1, which modified the guidelines for veterinary medical courses in Brazil, including an explicit recommendation to include professional training in ethics/bioethics.

Data were collected by administering a semi-structured questionnaire with closed-ended questions on sociodemographic data and training in bioethics and animal welfare. Year of graduation was a relevant variable.

One hundred forty veterinarians working at the Companbia Integrada de Desenvolvimento Agrícola de Santa Catarina (Agricultural Development Integrated Company of Santa Catarina; CIDASC) were surveyed. CIDASC is a state-owned company that operates across the state of Santa Catarina, Brazil. It comprises 17 regional departments and a central office located in Florianopolis, the state capital, where veterinarians work in animal health and animal product inspection. Both 
intentional and convenience sampling were used and included veterinarians trained at different schools and working across Santa Catarina state.

The questionnaire was completed after participants read and signed an informed consent form. The questionnaire was administered from May to August 2016, preferably at company-sponsored events such as meetings and training courses. To reach all veterinarians who worked at the company, the questionnaire and informed consent form were also sent by e-mail; thus, the professionals who did not participate in these events could also be included.

Pearson's chi-square and Fisher's exact tests were used in the statistical analysis. The data were analyzed using the statistical package Statistica 7.0 (StatSoft ${ }^{\circledR}$ ). Absolute and relative frequencies were calculated and compared between the groups.

\section{Results}

One hundred forty individuals completed the questionnaire: 62 (44.3\%) from Group 1 (having graduated through 2003) and 78 (55.7\%) from Group 2 (having graduated after 2003). Seventy-four respondents (53\%) were men, and 66 (47\%) were women, ranging in age from 31 to 61 years. Sixty-eight participants (48.6\%) graduated from schools in Santa Catarina, 52 (37.1\%) from schools in Rio Grande do Sul, 12 (8.6\%) from schools in Paraná, and 8 (5.7\%) from schools in Rio de Janeiro.

The responses regarding training and practical application of bioethics in professional practice are shown in Table 1. Bioethics was more frequently taught to participants in Group 2, mostly as an elective course. Bioethics was seldom taught together with other subjects. Participants considered applying bioethics to professional practice to be relevant and including bioethics in the university curricula and professional training to be necessary and fundamental, without significant differences between groups.

Table 1. Perception of bioethics training and practical application in professional practice per group.

\begin{tabular}{|c|c|c|c|c|c|}
\hline Questions & & Total & Group 1* & Group 2* & $p$ \\
\hline \multirow{2}{*}{ Were bioethics courses offered at your veterinary school? } & Yes & 11 & $1(1.6 \%)$ & $10(12.8 \%)$ & \multirow{2}{*}{0.003} \\
\hline & No & 129 & $61(98.4 \%)$ & $68(87.2 \%)$ & \\
\hline \multirow{3}{*}{ How was the bioethics course taught? } & Required & 2 & 0 & $2(2.6 \%)$ & \multirow{3}{*}{0.047} \\
\hline & Elective & 9 & $1(1.6 \%)$ & $8(10.2 \%)$ & \\
\hline & Not applicable & 129 & $61(98.4 \%)$ & $68(87.2 \%)$ & \\
\hline \multirow{2}{*}{$\begin{array}{l}\text { Was bioethics taught with other subjects at your veterinary } \\
\text { school? }\end{array}$} & Yes & 20 & $4(6.5 \%)$ & $16(20.5 \%)$ & \multirow{2}{*}{0.018} \\
\hline & No & 120 & $58(93.5 \%)$ & $62(79.5 \%)$ & \\
\hline \multirow{2}{*}{$\begin{array}{l}\text { Were the bioethics topics learned in veterinary school } \\
\text { applicable to veterinary practice? }\end{array}$} & Yes & 7 & $1(1.6 \%)$ & $6(7.7 \%)$ & \multirow{2}{*}{0.101} \\
\hline & Not applicable & 133 & $61(98.4 \%)$ & $72(92.3 \%)$ & \\
\hline \multirow{3}{*}{$\begin{array}{l}\text { Do you believe it is necessary for bioethics to be taught as a } \\
\text { required course in veterinary medicine undergraduate and } \\
\text { graduate programs? }\end{array}$} & Yes & 134 & $59(95.2 \%)$ & $75(96.2 \%)$ & \multirow{3}{*}{0.959} \\
\hline & No & 2 & $1(1.6 \%)$ & $1(1.2 \%)$ & \\
\hline & Do not know & 4 & $2(3.2 \%)$ & $2(2.6 \%)$ & \\
\hline \multirow{2}{*}{$\begin{array}{l}\text { Do you believe that bioethics is essential for the professional } \\
\text { training of veterinarians? }\end{array}$} & Yes & 134 & $58(93.6 \%)$ & 76 (97.4\%) & \multirow{2}{*}{0.259} \\
\hline & Do not know & 6 & $4(6.4 \%)$ & $2(2.6 \%)$ & \\
\hline
\end{tabular}

*Graduated in or before 2003; **Graduated after 2003.

The groups also agreed that bioethics topics are relevant and frequently applied in professional practice, especially bioethical principlism, with emphasis on beneficence, nonmaleficence, autonomy and justice. Attendance over the past 5 years at scientific development events that included bioethics was high in both groups (Table 2).

The participants' responses relative to animal welfare are listed in Table 3. More participants from Group 1 than from Group 2 stated that animal welfare was offered as a course; however, 
Table 2. Perception of the need for/relevance of bioethics for the profession and participation in events per group.

\begin{tabular}{|c|c|c|c|c|c|}
\hline Questions & & Total & Group $1^{*}$ & Group 2* & $p$ \\
\hline \multirow{2}{*}{$\begin{array}{l}\text { Could the use of bioethics tools, especially the bioethical } \\
\text { principles of beneficence, nonmaleficence, autonomy and } \\
\text { justice, help in your professional activities? }\end{array}$} & Yes & 127 & $54(87 \%)$ & $73(93.6 \%)$ & \multirow{2}{*}{0.177} \\
\hline & Do not know & 13 & $8(13 \%)$ & $5(6.4 \%)$ & \\
\hline How important is bioethics for practicing your profession? & Very important & 140 & $62(100 \%)$ & $78(100 \%)$ & - \\
\hline \multirow{2}{*}{$\begin{array}{l}\text { Have you participated in lectures, training courses or } \\
\text { conferences on bioethics in the past } 5 \text { years? }\end{array}$} & Yes & 127 & $57(91.9 \%)$ & $70(89.7 \%)$ & \multirow{2}{*}{0.657} \\
\hline & No & 13 & $5(8.1 \%)$ & $8(10.3 \%)$ & \\
\hline
\end{tabular}

*Graduated in or before 2003; **Graduated after 2003.

Table 3. Perception of animal welfare training and application in professional practice per group.

\begin{tabular}{|c|c|c|c|c|c|}
\hline Questions & & Total & Group 1* & Group $2^{* *}$ & $p$ \\
\hline \multirow{3}{*}{$\begin{array}{l}\text { Were animal welfare courses offered at your veterinary } \\
\text { school? }\end{array}$} & Yes & 111 & $59(95.2 \%)$ & $52(66.7 \%)$ & \multirow{3}{*}{0.0004} \\
\hline & No & 29 & $3(4.8 \%)$ & $26(33.3 \%)$ & \\
\hline & Required & 1 & $1(1.6 \%)$ & 0 & \\
\hline \multirow[t]{2}{*}{ How was the animal welfare course taught? } & Optional/ elective & 27 & $3(4.8 \%)$ & $24(30.8 \%)$ & \multirow[t]{2}{*}{$<0.0001$} \\
\hline & Not applicable & 112 & $58(93.6 \%)$ & $54(69.2 \%)$ & \\
\hline \multirow{2}{*}{$\begin{array}{l}\text { Were the animal welfare notions learned at school applicable } \\
\text { in veterinary practice? }\end{array}$} & Yes & 28 & $5(8.1 \%)$ & $23(29.5 \%)$ & \multirow{2}{*}{$<0.0001$} \\
\hline & Not applicable & 112 & 57 (91.9\%) & $55(70.5 \%)$ & \\
\hline \multirow{3}{*}{$\begin{array}{l}\text { Do you believe it is necessary to teach animal welfare as a } \\
\text { required course at veterinary medicine undergraduate schools? }\end{array}$} & Yes & 134 & 57 (91.9\%) & 77 (98.7\%) & \multirow{3}{*}{0.121} \\
\hline & No & 2 & $2(3.2 \%)$ & 0 & \\
\hline & Do not know & 4 & $3(4.9 \%)$ & $1(1.3 \%)$ & \\
\hline
\end{tabular}

${ }^{*}$ Graduated in or before $2003 ;{ }^{* *}$ Graduated after 2003.

when specifying whether the course was an elective or required, animal welfare courses were offered more often for Group 2 as an elective. Most participants from Group 2 answered that this subject has applications in professional practice and both groups stated that it should be taught as a required course at veterinary schools (Table 3 ).

In Table 4 are presented the participants' perceptions of animal welfare in professional practice. Regarding its practical application, both groups considered this subject to be essential for professional practice; however, the professional development rate for the past 5 years was low in both groups, without statistically significant differences.

Table 4. Perception of the need for/relevance of animal welfare for the profession and participation in events per group.

\begin{tabular}{|c|c|c|c|c|c|}
\hline Questions & & Total & Group $1^{*}$ & Group 2* & $p$ \\
\hline $\begin{array}{l}\text { Did the animal welfare topics that you learned have an } \\
\text { application in your professional practice? }\end{array}$ & Yes & 28 & $5(8.1 \%)$ & $23(29.5 \%)$ & $<0.001$ \\
\hline $\begin{array}{l}\text { Is knowledge about animal welfare needed to practice your } \\
\text { profession? }\end{array}$ & Yes & 140 & 62 (100\%) & 78 (100\%) & - \\
\hline \multirow{2}{*}{$\begin{array}{l}\text { Do you believe that animal welfare courses are essential for } \\
\text { veterinary practice? }\end{array}$} & Yes & 134 & $58(93.5 \%)$ & 76 (97.4\%) & \multirow{2}{*}{0.259} \\
\hline & Do not know & 6 & $4(6.5 \%)$ & $2(2.6 \%)$ & \\
\hline \multirow{2}{*}{$\begin{array}{l}\text { Have you participated in lectures, training courses or } \\
\text { conferences on animal welfare in the past } 5 \text { years? }\end{array}$} & Yes & 32 & $16(25.8 \%)$ & $16(20.5 \%)$ & \multirow{2}{*}{0.458} \\
\hline & No & 108 & $46(74.2 \%)$ & $62(79.5 \%)$ & \\
\hline
\end{tabular}

*Graduated in or before 2003; **Graduated after 2003. 
Regarding the geographical locations of the veterinary schools where the participants graduated, 3 participants (37.5\%) from schools in Rio de Janeiro, 3 (25\%) from Paraná, 4 (7.7\%) from Rio Grande do Sul, and none from Santa Catarina were taught bioethics as a standalone course. Thirteen participants (25\%) who graduated from schools in Rio Grande do Sul, 13 (19.1\%) from Santa Catarina, 2 (16.6\%) from Paraná, and 1 (12.5\%) from Rio de Janeiro were taught animal welfare as a standalone course. Among the participants who reported having been taught both subjects as a standalone or combined course, 4 (33.3\%) graduated from schools in Paraná, 15 (28.8\%) from Rio Grande do Sul, 16 (23.5\%) from Santa Catarina and 1 (12.5\%) from Rio de Janeiro.

\section{Discussion}

The number of participants who were taught courses that included bioethics content in veterinary school might be rated as low (7.85\%), especially considering that most participants had graduated after 2003, when CNE/CES Resolution no. 1/2003 recommending inclusion of these subjects in teaching was published. Only $1.6 \%$ and $12.8 \%$ of participants were offered bioethics before and after 2003, respectively, indicating a partial lack of compliance with the National Curriculum Guidelines for veterinary medical courses, which are responsible for training future veterinarians. A similar result was obtained in a study, which found that students acquired bioethics knowledge on animal use in practical activities as part of nonspecific courses (Lima et al., 2008). In the present study, all participants rated bioethics as very relevant for professional practice, and most believed that bioethical tools might help them in their professional activities (Tables 1 and 2).

Reflection and systematic inclusion of bioethics in curricula tends to increase simultaneously with changes in professors' attitudes toward animals (Lima et al., 2008). Although most participants in the present study (58.3\%) stated they had been taught some bioethical ideas, a significant proportion (41.7\%) had not. A study conducted with veterinary medicine and biological science students in Paraná found that only $24.7 \%$ of participants reported having been taught bioethics before graduation, but all of them rated it significant (Duzanski et al., 2015). In the present study, most participants from Rio de Janeiro and Paraná reported that their schools taught bioethics as an autonomous discipline. This finding suggests a possible trend toward greater access to this subject, although it is far from the ideal formulated in the National Curriculum Guidelines for Veterinary Medicine (Brasil, 2003).

Direct contact with animals is indispensable for training veterinarians, usually within the context of courses on surgical techniques and surgical pathology. However, these practices have been questioned by professionals, students and nongovernmental animal welfare organizations, among others. Reasons for this criticism include awareness of the ethical principles for using animals in practical activities and minimizing animal use in such activities, which has led universities to discourage their use (Rodrigues et al., 2013; Duzanski et al., 2015). Consequently, with repercussions on the Brazilian National Congress, the Arouca Law (Brasil, 2008) was passed. While this law permits animal use when necessary, it sets limits and care measures and demands previous authorization from a CEUA, which are mandatorily established at teaching and research institutions (Brasil, 2008).

The number of participants who were taught animal welfare was higher than the number taught bioethics, independent of graduation year. The proportion of participants who were taught elective or required courses on animal welfare increased from 6.4\% in Group 1 to 30.8\% in Group 2. In Brazil, animal welfare courses were first taught at undergraduate schools in 1999 (Souza, 2006). In contrast to what was expected, the present study found that more participants from Group 1 reported having been taught animal welfare in undergraduate school. However, most responded "not applicable" to the question on the nature-elective or required-of these courses, suggesting that this subject was not approached in systematic or organized courses as established by the National Curriculum Guidelines, but within other courses.

Universities seek to improve relationships with animals, and all involved professions should undergo this change to provide better care and attribute proper value to animal welfare (Borges et al., 2013). Animal welfare deserves more attention so that professionals are trained to think, argue and solve issues in their professional practice (Fraser et al., 2013). Teaching animal welfare by providing information and raising awareness about its relevance is an essential component of the process of changing attitudes and developing reflection skills among future veterinarians 
(Fischer \& Tamioso, 2016). In this regard, more participants who graduated after 2003 stated that animal welfare has practical applications in professional practice.

Organización Internacional de Salud Animal (2013) recommended teaching animal welfare as a required course. However, some veterinary schools have not yet done so, nor have they provided future veterinarians the tools needed to promote changes in the attitudes toward animal treatment. Only 1 participant (0.7\%) in the present study reported having been taught animal welfare as a required discipline, which suggests that it is still early in the process of including this subject in undergraduate veterinary school curricula (Table 3). However, this trend is increasing; in 2013, 46\% of veterinary schools offered some form of animal welfare course in Brazil (Borges et al., 2013).

Including animal welfare courses in veterinary curricula will favor training professionals to be better prepared to address the challenges posed by recent advances in science and ethics (Faraco, 2014). A study with thirteen veterinary schools across several continents found that only one school in Brazil taught an animal welfare course (Federal University of Paraná), while six schools did not (Hewson et al., 2005). Consistent with Duzanski et al. (2015) study, most participants in the present study rated teaching animal welfare and bioethics as essential and necessary for professional practice (Tables 2 and 4 ). In addition, all participants stated that animal welfare should be a required course, thus indicating that veterinarians are receptive to teaching this subject and that higher education institutions should provide these courses systematically.

More participants from Paraná and Rio Grande do Sul reported studying bioethics and animal welfare before graduation, but the proportion was still low. When future veterinarians acquire sound ethical and scientific training and knowledge on animal welfare, they gain the potential to develop desirable professional skills such as sensitivity and empathy (Ballesteros, 2012). Technical-scientific discussions permeated by bioethical discussions in which animal rights prevail should guide the integral training of professionals responsible for animal welfare (Londoño \& Assmus, 2013).

The new Code of Ethics for Veterinarians that was approved through Resolution no. 1,183 in December 2016 by the CFMV and the various Conselhos Regionais de Medicina Veterinária (Veterinary Medicine Regional Councils; CRMV) became law on 9 September 2017. The code includes articles that focus on animal welfare and thus represents an advance from the previous code, which did not consider this notion (Conselho Federal de Medicina Veterinária, 2016). Acknowledging the sentience of nonhuman animals and including animal welfare in the professional Code of Ethics, together with National Curriculum Guidelines that recommend teaching bioethics in undergraduate courses, suggests the need to pay more attention to bioethics and animal welfare in training future veterinarians to subsequently improve some of the present study's unsatisfactory findings (Low, 2012; CFMV, 2016; Brasil, 2003).

\section{Conclusions}

Comparing veterinarians from both groups, the frequency of bioethics and/or animal welfare courses increased, however, this increase was smaller than expected given the National Curriculum Guidelines for veterinary medicine and the OIE's support for developing animal welfare in developing countries since 2013. Based on this trend, approving the new Code of Ethics for Veterinarians, enforced since 2017, should significantly strengthen the inclusion of bioethics more substantially and explicitly in veterinary school curricula to effectively consolidate training in bioethics before graduation.

The new moral conflicts in professional and social spheres, given society's increased awareness of this issue after recent scientific advances and the acknowledgment of animals as sentient beings evidence the need for greater urgency in improving bioethics and animal welfare training for future veterinarians.

A group of professionals, in their own perception, received insufficient training in bioethics and animal welfare but are aware of their benefits and need in everyday veterinary practice. Thus, one might infer that improving bioethics and animal welfare teaching at veterinary schools will provide society more conscientious and sensitive veterinarians who can defend all forms of life, with high quality in its entirety and advocate for the rights of non-human animals, who are sentient and, thus, deserve the most humane care possible. 


\section{References}

Ballesteros, E. E. T. (2012) El uso de los animales en la educación. Un análisis bioético. Murmullos filosóficos, 2(3), 52-59.

Borges, T. D., Sans, E. C. O., Braga, J. S., Machado, M. F., \& Molento, C. F. M. (2013). Ensino de bem-estar e dor animal em cursos de medicina veterinária no Brasil. Arquivo Brasileiro de Medicina Veterinária e Zootecnia, 65(1), 29-36. http://dx.doi.org/10.1590/S0102-09352013000100005.

Brasil, Ministério da Educação, Conselho Nacional de Educação, Câmara de Educação Superior. (2003, 20 de fevereiro). Institui Diretrizes Curriculares Nacionais dos Cursos de Graduação em Medicina Veterinária (Resolução CNE/CES 1, de 18 de fevereiro de 2003). Diário Oficial da República Federativa do Brasil. Seção 1:22. Recuperado em 06 de setembro de 2017, de http://portal.mec.gov.br/cne/arquivos/pdf/ces012003.pdf

Brasil. (2008, 08 de outubro). Regulamenta o inciso VII do §1o do art. 225 da Constituição Federal, estabelecendo procedimentos para o uso científico de animais; revoga a Lei $n^{\circ} 6.638$, de 8 de maio de 1979; e dá outras providências (Lei no 11.794, de 8 de outubro de 2008). Diário Oficial da República Federativa do Brasil. Recuperado em 06 de setembro de 2017, de http://www.planalto.gov.br/ccivil_03/_ato2007-2010/2008/lei/111794.htm

Brasil. (2009, 15 de julho). Dispõe sobre a composição do Conselho Nacional de Controle de Experimentação Animal - CONCEA, estabelece as normas para o seu funcionamento e de sua Secretaria-Executiva, cria o Cadastro das Instituições de Uso Científico de Animais - CIUCA, mediante a regulamentação da Lei no 11.794, de 8 de outubro de 2008, que dispõe sobre procedimentos para o uso científico de animais, e dá outras providências (Decreto no 6.899, de 15 de julho de 2009). Diário Oficial da República Federativa do Brasil. Recuperado em 06 de setembro de 2017, de http://www.planalto.gov.br/ccivil_03/_Ato2007-2010/2009/Decreto/D6899.htm

Carvalho, S. M. C., Sousa, W. L., Rodrigues, A. A., Sá, M. V., Sá, I. S., Batista, R. M. O., Rocha, D. S., Santos, J. S., Galeno, L. S., \& Machado Júnior, A. A. N. (2018). Atendimento clínico veterinário em cães e gatos na comunidade Serra Nova do município de Bom Jesus-PI. Pubvet, 12(2), 1-4. http://dx.doi.org/10.222256/pubvet.v12n2a40.1-4.

Conselho Federal de Medicina Veterinária. (2016, 25 de janeiro). Aprova o Código de Ética do Médico Veterinário (Resolução no 1138, de 16 de dezembro de 2016). Diário Oficial da República Federativa do Brasil. Recuperado em 15 de outubro de 2017, de http://portal.cfmv.gov.br/portal/noticia/index/id/5001

Duzanski, A. D. P., Santos, A. P. M. E., Cruz, M. F. R., Porto, E. D. P., Porto, P. P., Silva, M. A. A., Marquez, E. D. S., \& Silva, C. F. G. K. T. (2015). Sentiency, bioethics and animal welfare: concepts that need to be discussed in higher education to change the teaching and researching paradigm. Semina: Ciências Agrárias, 36(6), 4031. http://dx.doi.org/10.5433/1679-0359.2015v36n6p4031.

Faraco, C. B. (2014, Agosto 5-7) Inserção do bem-estar animal no currículo de medicina veterinária. In Anais do III Congresso de Medicina Veterinária Brasileiro (pp. 159-162). Curitiba, Paraná: CFMV. Recuperado em 24 de setembro de 2017, de http://portal.cfmv.gov.br/uploads/anaisIII.pdf

Fischer, M. L., \& Tamioso, P. R. (2016). Bioética ambiental: concepção de estudantes universitários sobre o uso de animais para consumo, trabalho, entretenimento e companhia. (2016). Ciência \& Educação, 22(1), 163-182. http://dx.doi.org/10.1590/1516-731320160010011.

Fraser, D., Duncan, I. J. H., Edwards, S. A., Grandin, T., Gregory, N. G., Guyonnet, V., Hemsworth, P. H., Huertas, S. M., Huzzey, J. M., Mellor, D. J., Mench, J. A., Spinka, M., \& Whay, H. R. (2013). General Principles for the welfare of animals in production systems: The underlying science and its application. Veterinary Journal, 198(1), 19-27. http://dx.doi.org/10.1016/j.tvjl.2013.06.028. PMid:23899406.

Hewson, C. J., Baranyiova, E., Broom, D. M., Cockram, M. S., Galindo, F., Hanlon, A. J., Hanninen, L., Lexer, D., Mellor, D. J., Molento, C. F. M., Odberg, F. O., Serpell, J. A., Sisto, A. M., Stafford, K. J., Stookey, J. M., \& Waldau, P. (2005). Approaches to Teaching Animal Welfare at 13 Veterinary Schools Worldwide. Journal of Veterinary Medical Education, 32(4), 422-37.

Lima, K. E. C., Mayer, M., \& Carneiro-Leão, A. M. (2008) Conflito ou convergência? Percepções de professores e licenciandos sobre ética no uso de animais no ensino de zoologia. Investigações em Ensino de Ciências, 13(3), 353-69.

Londoño, I. C., \& Assmus, G. C. (2013). Enseñanza de la medicina veterinaria, bioética y uso de las TIC. Revista de la Universidad de La Salle, 60, 177-191. https://revistas.lasalle.edu.co/index.php/ls/article/view/2390/2135

Low, P. (2012). The Cambridge Declaration on Consciousness (J. Panksepp, D. Reiss, D. Edelman, B. Van Swinderen, P. Low \& C. Koch, eds.). Cambridge: University of Cambridge. Recuperado em 06 de junho de 2017, de http:// fcmconference.org/img/CambridgeDeclarationOnConsciousness.pdf

Organización Internacional de Salud Animal. (2013). Plan de Estudios Básico de Formación Veterinaria: Directrices de la OIE. Recuperado em 14 de agosto de 2017, de http://www.oie.int/Plan_de_Estudios_Basico_de_Formacion_ Veterinaria.pdf

Organización Internacional de Salud Animal. (2012). Recomendaciones de la OIE sobre las competencias mínimas que se esperan de los veterinarios recién licenciados para garantizar Servicios Veterinarios Nacionales de calidad. Recuperado em 18 de julho de 2017, de http://www.oie.int/fileadmin/Home/esp/Support_to_OIE_Members/ Edu_Vet_AHG/day_1/DAYONE-B-esp-VC.pdf

Rodrigues, D. F., Mendes, F. F., \& Silva, L. A. F. (2013). Alternativa ao uso de animais no ensino da cirurgia veterinária e a Escola de Veterinária e Zootecnia da Universidade Federal de Goiás: Revisão. Medicina Veterinária, 7(3), 47-58.

Souza, M. F. A. (2006). Introdução aos Conceitos de Bem-Estar Animal nas faculdades de Medicina Veterinária e Zootecnia do Brasil (CBEA) (Relatório de projeto). Sociedade Mundial de Proteção Animal - WSPA, Rio de Janeiro. 68p. 